\title{
SOME PHYSICAL PROPERTIES OF RICE STRAW BRIQEUTTES
}

\section{El-Soaly I. S. ${ }^{*}$, R.R. EL-Bessoumy ${ }^{* *}$ and A. E. M. Fodah ${ }^{* * *}$ \\ ABSTRACT}

The main objective of the present study is to develop the fundamentals of a technology for energetic utilization of rice straw aimed at solving the problem of harmful storing and burning of rice straw in Egypt and preventing the smoke clouds caused by this and handling via the right way that is safe for both the environment and agriculture, producing a cheap, easily storable, and environmentally sound biofuel for rural areas in Egypt. Chopped rice straw was densified into briquettes using a laboratory model vertical hydraulic press at different formation pressures of $(15,32,49$ and $60 \mathrm{MPa})$, three temperature (room temperature $\left(35^{\circ} \mathrm{C}\right), 75$ and $\left.100^{\circ} \mathrm{C}\right)$, three level of moisture content (6.53, 8.90 and $10.26 \% \mathrm{wb}$ ) and different holding time (10, 20 and $30 \mathrm{~min}$ ). The results showed that the highest bulk density, compression ratio, durability and water resistance were $1337 \mathrm{~kg} / \mathrm{m}^{3}, 18,95 \%$ and $107 \mathrm{~min}$, respectively, at formation pressure of $60 \mathrm{MPa}$, temperature of $100^{\circ} \mathrm{C}$, moisture content of $6.53 \%$ and holding time of $30 \mathrm{~min}$. While, the minimum resiliency obtained was $6.53 \%$. The $\mathrm{CO}, \mathrm{CO}_{2}$ and $\mathrm{NO}_{x}$ emissions values for rice straw briquettes decreased by 69, 54 and $37 \%$, respectively, of the emissions values $\mathrm{CO}, \mathrm{CO}_{2}$ and $\mathrm{NO}_{x}$ for chopped rice straw. The combustion efficiency was $99 \%$ and $70 \%$ for rice straw briquettes and chopped rice straw, respectively, and the burning time was about 74 and 15 min for rice straw briquettes and chopped rice straw, respectively.

\section{INTRODUCTION}

7 he availability of energy for domestic use in Egypt continues to pose a formidable challenge, especially with the high cost of

cooking gas and kerosene and the environmental problems associated with firewood.

\footnotetext{
*Prof. of Agric. Eng., Faculty of Agric. Eng., Al-Azhar Univ.

**Ass. Prof. of Agric. structures and environmental control Dept., Faculty of Agric. Eng., Al-Azhar Univ.

***Demons. of Agric. structures and environmental control Dept., Faculty of Agric. Eng., Al-Azhar Univ.
} 
Alternative forms of energy need to be sourced. This has necessitated the need to improve on the use of agro wastes such as rice-husk and corn stalks as alternatives. Numerous agricultural residues and wastes are generated in the country, but they are poorly utilized and badly managed, since most of these wastes are left to decompose or they are burned in the field resulting in environmental pollution and degradation (Jekayinfa and Omisakin, 2005). However, scientific studies have concluded that a lot of potential energy abounds in these residues (Fapetu, 2000). In Egypt, disposal of crop residues are one of the main problems facing Egyptian farmers which estimates about 30 to $35 \mathrm{Tg} /$ year. Rice straw is considered as the one of the main environmental problems in Egypt. It is estimated to be around $3.13 \mathrm{Tg}$ every year and these residues are left to rot away or they are burned like other agricultural wastes (MALR, 2013). These residues could however, be used to generate heat for domestic and industrial cottage applications (Fapetu, 2000). Farmers used these residues as fuel resources for the traditional mud ovens in which their families cooked and baked. For this purpose, farmers stored these residues on the roofs of their houses or on the fields. This traditional way of handling these residues caused several problems such as, a good habitat for insects, mice and snakes that developed in the pile and increased the risk of destructive fire in the villages. The burning of agricultural wastes causes air pollution, soil erosion, and a decrease in biological activity, which eventually leads to lower yields however, burning yields smoke and other pollutants which adversely affect air quality, visibility, and human and environmental health. One of the promising solutions to these problems is the application of briquetting technology (Wilaipon, 2007). The technology may be defined as a densification process for improving the handling characteristics of raw materials and enhancing volumetric calorific value of the biomass. Environmentally, pellet biomass fuels provide advantages of less ash, smoke and other compound emissions, including carbon particles, $\mathrm{CO}$, $\mathrm{NO}_{\mathrm{x}}$ and $\mathrm{SO}_{\mathrm{x}}$. Because the use of biomass pellets produces much fewer greenhouse gases when the biomass is sustainably harvested, there has been a recent push to replace fossil fuels with biomass fuels (Panwar, $\boldsymbol{e t}$ al 2011). To make the biomass materials available for a variety of 
applications, the challenges with the use of biomass materials in their original form must be resolved. Because of high moisture content, irregular shape and sizes, and low bulk density, biomass is very difficult to handle, transport, store, and utilize in its original form. One of the solutions to these problems is densification of biomass materials into pellets, briquettes, or cubes. Densification increases the bulk density of biomass from an initial bulk density (including baled density) of 40-200 $\mathrm{kgm}^{-3}$ to a final bulk density of $600-800 \mathrm{~kg} / \mathrm{m}^{3}$ (Mullen, et al 2005). Densification process to create strong and durable bonding in densified products such as pellets, briquettes, and cubes can be determined by quality testes which include testing the strength (compressive resistance, impact resistance and water resistance) and durability (abrasion resistance) of the densified products These tests can indicate the maximum force/stress that the densified products can withstand, and the amount of fines produced during handling, transportation and storage (Nalladurai and Morey 2009). The durability of briquettes is a measure of the ability of the briquettes to withstand the destructive forces such as compression, impact and shear during handling and transportation. In addition, the durability values represent the relative strength of the particle-particle bonding in the briquettes/pellets (Nalladurai and Morey 2010). The process of forming biomass into briquettes depends upon the physical properties of ground particles and the process variables during pelletizing, pressure and temperature. Fuel briquettes were produced under different conditions to have different handling characteristics. These characteristics were found to be strongly affected by raw material properties. Briquette density is one of the most important properties which bear on the combustion characteristics, handling characteristics including the ignition behavior of briquettes. This property depends on several factors therefore, it is crucial to understand the effects of these factors on briquette density. Among the factors, die pressure seems to be one of the most important ones. The correlations of briquette density as a function of die pressure for the produced briquettes from several kinds of agricultural residues were studied. Another relationship between die pressure and the density was also purposed for the case of palm fiber and palm shell briquettes (Chin and Siddiqui 2000). 
The study was carried out to evaluate some physical properties of rice straw briquettes.

\section{MATERIALS AND METHODS}

The objectives of the present work are to evaluate some physical properties of rice straw briquettes, also producing a cheap, easily storable, and environmentally sound biofuel for rural areas in Egypt.

The experimental part of the present work was carried out in the faculty of Agricultural Engineering, Al-Azhar University, Cairo, during summer of 2015 .

\section{Raw materials (rice straw):}

The rice straw was chosen in this study because this residue is one of the main problems facing Egyptian farmers and the huge amounts of this residues in Egypt which was about $3.13 \mathrm{Tg}$ /year, (MALR, 2013). The rice straw were collected from fields of Kafr El-Sheikh governorate during harvesting seasons of 2014/2015.

The rice straw (Oryza Sativa) variety used was Giza 101 from season 2014. The stem average length was about $800 \mathrm{~mm}$ (from 700 to 900 $\mathrm{mm}$ ), stem diameter ranged from 3 to $4.5 \mathrm{~mm}$ and number of branches ranged from 5 to 12 (Gamea et al.,2012). The rice straw was chopped by using a grinding machine in the workshop of Agricultural Engineering Faculty, Al-zhar University, Cairo, Egypt. The chopped rice straw were collected and put in plastic bags until to be used. Random samples were taken after grinding process for measuring lengths distribution by using four standard sieves. The selected sieves series were based on the range of particles in the sample, the lengths distribution of these chops as show in Table (1). The particles size was determined according to ANSI/ASAE standard S319.3JUL97- 1996. The bulk density for chopped rice straw was $75 \mathrm{~kg} / \mathrm{m}^{3},(4.2 \% \mathrm{CV})$.

Table (1): Lengths distribution of grinded rice straw.

\begin{tabular}{|c|c|c|c|c|c|}
\hline Particle size (mm) & $\begin{array}{c}\text { Less than } \\
\mathbf{0 . 7}\end{array}$ & $\mathbf{0 . 7}$ to 1 & $\mathbf{1}$ to $\mathbf{1 . 4}$ & $\mathbf{1 . 4}$ to $\mathbf{2 . 8}$ & total \\
\hline Mass of Particle (g) & 5.53 & 10.20 & 6.35 & 17.92 & 40 \\
\hline $\begin{array}{c}\text { Percentage of } \\
\text { Particle lengths (\%) }\end{array}$ & 13.98 & 25.18 & 15.95 & 44.89 & 100 \\
\hline
\end{tabular}




\section{A pressing apparatus:}

The pressure was used in this study as an important variable to perform briquettes from rice straw. The hydraulic pressure as shown in Fig. (1) was used in this study as a pressing apparatus.

\section{Pressing cylinder:}

A cylinder was used to compress samples inside it which manufactured from mild steel in the workshop of Faculty of Agricultural Engineering, Al-Azhar University, Cairo. Its inner diameter of $70 \mathrm{~mm}$, outer diameter of $75 \mathrm{~mm}$ and length of $200 \mathrm{~mm}$. In order to compress the sample inside the pressing cylinder, two disks of steel were used. The diameters of disks were $69 \mathrm{~mm}$. The upper and lower disks thicknesses were done to be $20 \mathrm{~mm}$. Fig. (2) illustrate the isometric of the pressing cylinder and disks.
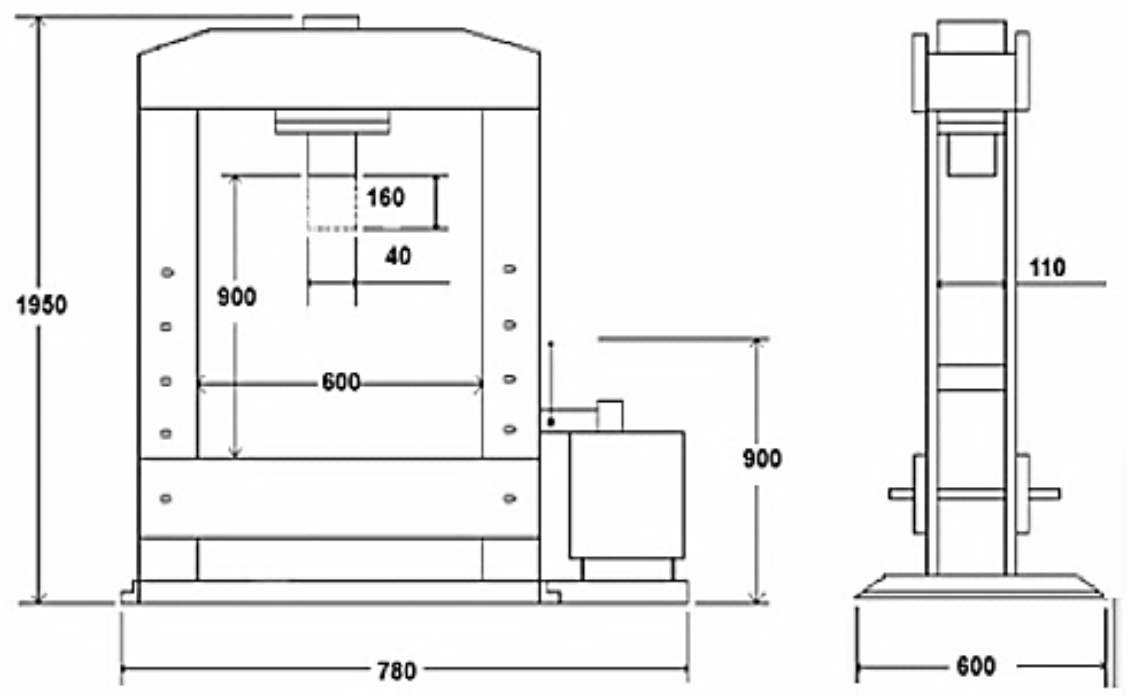

Fig. (1): Schematic diagram of pressing apparatus dimensions in $\mathbf{m m}$.

\section{Heating unit:}

Two cylindrical heaters were used; each one of the used heaters had the same dimensions and electrical specifications. The heater diameter of 70 $\mathrm{mm}$, thickness of $20 \mathrm{~mm}$, height longed $100 \mathrm{~mm}$ and power requirement of 300 watt. Fig. (2) illustrate the isometric diagram of the heating unit.

\section{Briquettes durability instrument (DU):}

Durability of briquettes was measured because the durability is one of the main properties that describes the physical quality of densified solid 
biofuels briquettes. This type of fuel is a susceptible to mechanical wear, which leads to production of fine particles or dust during transport, transshipment and storage. Durability of briquettes was measured according to the standard method of ASAE S269.4 (1996). The briquettes durability instruments consist of an electrical motor and tumbling box. The tumbling box was rotated about an axis, which was perpendicular to and centered in the $300 \mathrm{~mm}$ side. A long baffle of 230 mm was affixed symmetrically and diagonally to a side of the box (300* $300 \mathrm{~mm})$.

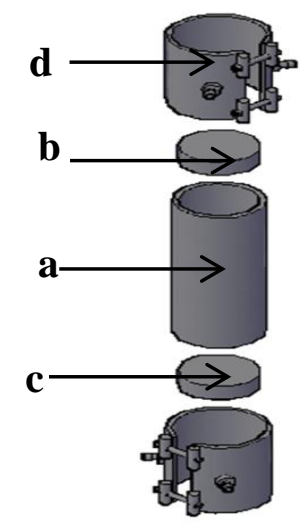

Fig. (2): Pressing cylinder, disks and heating units. (a) Pressing cylinder, (b) Upper disk, (c) Lower disk, (d) Heating units.

\section{Fuel gas analyzer:}

The gases emissions, combustion efficiency and burning time were measured by using analyzer IMR 1400. The estimated gases emissions were carbon monoxide $(\mathrm{CO})$, carbon dioxide $\left(\mathrm{CO}_{2}\right)$ and oxides of nitrogen $\left(\mathrm{NO}_{\mathrm{X}}\right)$.

\section{Sample adjustment for pressing:}

Each sample had a constant mass of $40 \mathrm{~g}$. The sample was put inside a pressing cylinder and compressed between two disks by hydraulic pressing at a selected loading level. The thickness of sample was recorded after pressing process to calculate the bulk density. Fig. (3) illustrated the specimens after pressing and before testing. 


\section{Measurements:}

\section{Bulk density $\left(\rho_{\mathrm{b}}\right)$ :}

The bulk density of the briquettes is the most important factors that must be study because its affect the regularity of the combustion process.

The samples thickness was recorded after pressing to calculate the bulk density at different conditions using the following equation (1), (Jha et al 2008):

$$
\begin{gathered}
\rho_{\mathrm{b}}=\frac{M}{V} \\
\mathrm{~V}=\pi r^{2} * t
\end{gathered}
$$

Where:

$\rho_{\mathrm{b}}$ : Bulk density, $\mathrm{kgm}^{-3}$;

$\mathrm{V}$ : Volume of briquette, $\mathrm{m}^{3}$;

M: Mass of briquette, $\mathrm{kg}$;

$\mathrm{r}$ : Radius of briquette, $\mathrm{mm}$; and

$\mathrm{t}$ : Thickness of briquette, $\mathrm{mm}$.

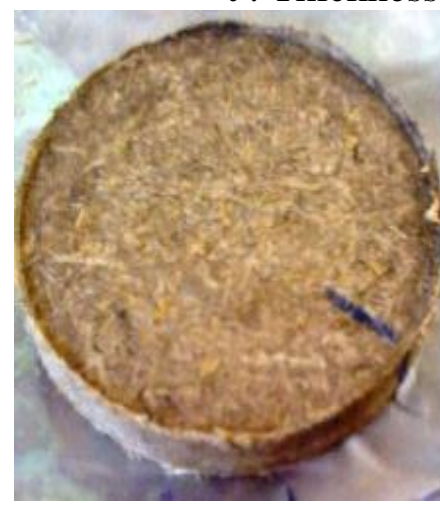

a

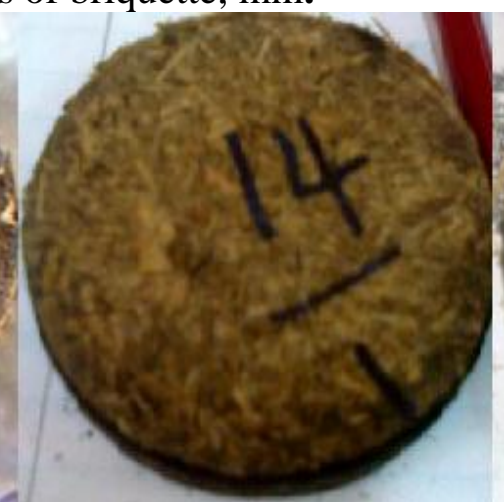

b

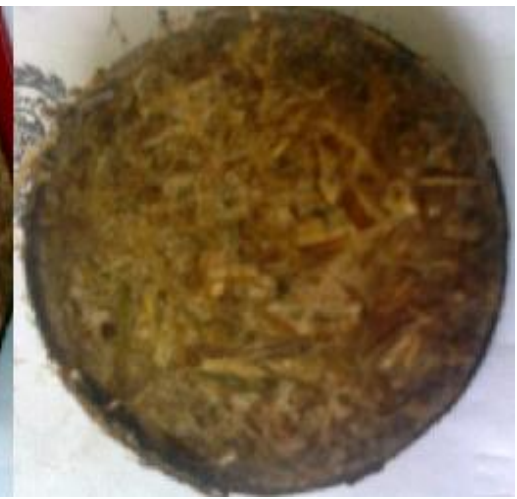

c

Fig. (3): Specimens of rice straw briquettes (a: without heat, $b$ and $c$ are heated at $75^{\circ} \mathrm{C}$ and $100{ }^{\circ} \mathrm{C}$, respectively) after pressing and before testing.

\section{Compression ratio $(\mathbf{C R})$ :}

The compression ratio indicates the volume reduction during compression. It was obtained from the ratio of bulk density of briquettes to the initial bulk density of chopped rice straw before pressing process using the following equation (3), (Jha et al 2008). 


$$
\boldsymbol{C R}=\frac{\boldsymbol{\rho}_{b}}{\rho_{\text {raw }}} \quad \ldots \ldots \ldots \ldots
$$

Where:

CR: Compression ratio;

$\rho_{b}$ : Bulk density of rice straw briquettes, $\mathrm{kgm}^{-3}$;

$\rho_{\text {raw }}$ : Bulk density of chopped rice straw, $\mathrm{kgm}^{-3}$.

\section{Resiliency (R):}

At the end of the compression process and after releasing the samples from the compression cylinder, the resiliency (samples thickness recovery) was measured at different durations; varying from 5 min to 24 h. Resiliency indicates the elastic property of the material. It was determined as the ratio of increased thickness to the initial thickness of the briquettes. The thickness of the briquettes was measured after duration of $5 \mathrm{~min}, 30 \mathrm{~min}$ and $24 \mathrm{~h}$ respectively using the following equation (4), (Jha et al 2008).

$$
\mathbf{R}=\frac{\text { th }- \text { thi }}{\text { thi }} * 100
$$

Where:

$\mathrm{R}:$ Resiliency \%;

th : Thickness of stabilized briquettes, $\mathrm{mm}$; and

thi : Initial thickness of briquettes, $\mathrm{mm}$.

\section{Water resistance:}

The water resistance of the briquettes was achieved by immersing them in a glass container filled with cold tap water at $20-25^{\circ} \mathrm{C}$. The required time ( $\mathrm{min}$ ) was recorded for dispersion the briquettes in the water, (Yaman, et al 2001 and Debdoubi, et al 2004).

\section{Durability (DU):}

Before carrying out this test, samples of the medium and high moisture content $(8.90 \%, 10.26 \%)$, respectively, were not used for rice straw, due to that the previous medium and high moisture content didn't gave desired values of bulk density, compression ratio, resiliency and water resistance. The durability $(\mathrm{Du})$ of the produced briquettes was determined according to ASAE Standard S269.4, 1996. Sample of $500 \mathrm{~g}$ briquettes was tumbled in the box at $50 \mathrm{rpm}$ for $10 \mathrm{~min}$. Durability is expressed by the percent ratio of mass of briquettes retained on the sieve 
after tumbling ( $m p a)$ to mass of briquettes before tumbling $(m p b)$ in accordance with the following equation (5) (El-Saeidy, 2004).

$$
\mathrm{Du}=\frac{m p a}{m p b} * 100
$$

\section{Gases emission:}

This test was carried out for chopped corn stalks and rice straw (raw material), as well as for the produced corn stalks and rice straw briquettes. The samples characteristics that used in this test are shown in table (3.4). Gasoline was used as an assistant in the begin of the burning process. The sample was put inside the stove after regularity of the ignition process. The gases emissions, combustion efficiency and burning time were recorded from the chimney height of $160 \mathrm{~cm}$. the gases emissions, $\left(\mathrm{CO}, \mathrm{CO}_{2}\right.$ and $\left.\mathrm{NO}_{\mathrm{x}}\right)$, were recorded each 15 min during incineration process.

Table (2): Characteristics of samples that used for combustion.

\begin{tabular}{|lc|c|c|}
\hline \multirow{2}{*}{ Parameter } & \multicolumn{2}{|c|}{ Rice straw } \\
\cline { 3 - 4 } & $\mathbf{m m}$ & 1 to 3 & Briquette \\
\hline Length & $\mathbf{m m}$ & -------- & 7.78 \\
\hline Diameter & $\mathbf{\%}$ & 6.53 & 4.63 \\
\hline Moisture content & $\mathbf{k g} / \mathbf{m}^{\mathbf{3}}$ & 75 & 1337 \\
\hline Bulk density & $\mathbf{g}$ & 80 & 80 \\
\hline Mass & & & \\
\hline
\end{tabular}

\section{RESULTS AND DISCUSSION}

Effect of studied variables (formation pressure, moisture content, temperature and holding time) on bulk density for rice straw briquettes:

The bulk density for the briquettes is the most important property that must be studied because they affect the regularity of the combustion process and an indicator for the compression ratio. It also, helps to solve the problems of biomass storage. The measured density of the chopped rice straw was about $75 \mathrm{~kg} / \mathrm{m}^{3}$. On the other hand, the briquette density of $6.53 \%$ moisture content was $1337 \mathrm{~kg} / \mathrm{m}^{3}$. The increasing density was more than $1700 \%$, that means one ton of the loose material will take a 
storage place of about $13.3 \mathrm{~m}^{3}$. On the other hand, one ton of the briquette of $6.53 \%$ moisture content will take a storage place of about $0.75 \mathrm{~m}^{3}$; the change in the storage place briquettes than the loose materials is about $94 \%$. Fig (4) illustrates the relationship between bulk density $\left(\mathrm{kg} / \mathrm{m}^{3}\right)$ and formation pressure (MPa) at different holding time (min), moisture contents $(\%)$ and temperatures $\left({ }^{\circ} \mathrm{C}\right)$ for rice straw briquettes. The maximum bulk density obtained was about $1337 \mathrm{~kg} / \mathrm{m}^{3}$ at formation pressure $60 \mathrm{MPa}$, moisture content $6.53 \%$, temperature $100^{\circ} \mathrm{C}$ and holding time $30 \mathrm{~min}$. While, the minimum bulk density obtained was about $555 \mathrm{~kg} / \mathrm{m}^{3}$ at formation pressure $15 \mathrm{MPa}$, moisture content $10.26 \%$, room temperature $\left(35^{\circ} \mathrm{C}\right)$ and holding time $10 \mathrm{~min}$. This result is in agreement with that published by El-Saeidy (2004).

Effect of studied variables (formation presser, moisture content, temperature and holding time) on compression ratio for rice straw briquettes:

Compression ratio was calculated depending on the bulk density for all experimental results. Fig (5) illustrates the relationship between compression ratio $\left(\mathrm{kg} / \mathrm{m}^{3}\right)$ and formation pressure $(\mathrm{MPa})$ at different holding time $(\mathrm{min})$, moisture contents $(\%)$ and temperatures $\left({ }^{\circ} \mathrm{C}\right)$ for rice straw briquettes. The data indicated that the compression ratio increases with formation pressure, temperatures and holding time increasing. While, compression ratio decreases with moisture contents increasing.

The maximum compression ratio obtained was about 18 at the formation pressure $60 \mathrm{MPa}$, moisture content $6.53 \%$, temperature $100^{\circ} \mathrm{C}$ and holding time $30 \mathrm{~min}$. While, the minimum compression ratio obtained was about 7 at formation pressure $15 \mathrm{MPa}$, moisture content $10.26 \%$, room temperature $\left(35^{\circ} \mathrm{C}\right)$ and holding time $10 \mathrm{~min}$. This result is in agreement with that published by Jha et al. (2008).

\section{Effect of studied variables on resiliency for rice straw briquettes:}

Fig (6) illustrates the relationship between resiliency and formation pressure $(\mathrm{MPa})$ at different holding time $(\mathrm{min})$, moisture contents $(\%)$ and temperatures $\left({ }^{\circ} \mathrm{C}\right)$ for rice straw briquettes. The data indicated that the resiliency decreases with formation pressure, temperatures and holding time increasing. While, resiliency increases with moisture contents increasing. 


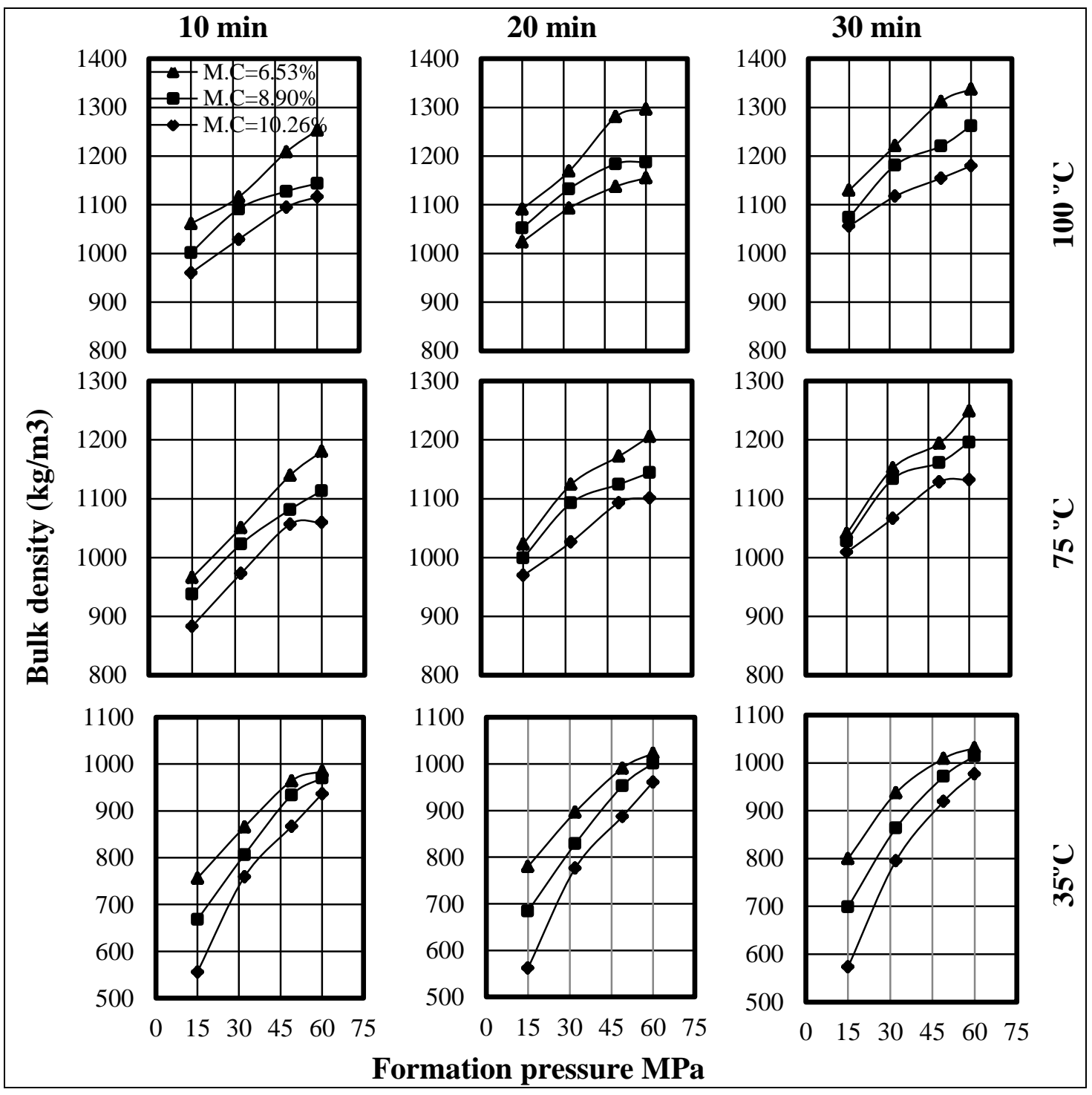

Fig. 4: Effect of formation pressure (MPa) on bulk density $\left(\mathrm{kg} / \mathrm{m}^{3}\right)$ at different holding times $(\mathrm{min})$, moisture contents $(\%)$ and temperatures $\left({ }^{\circ} \mathrm{C}\right)$.

The maximum resiliency obtained was about $92 \%$ at formation pressure $15 \mathrm{MPa}$, moisture content $10.26 \%$, room temperature $\left(35^{\circ} \mathrm{C}\right)$ and holding time $10 \mathrm{~min}$. While, the minimum resiliency obtained was about $7.11 \%$ at formation pressure $60 \mathrm{MPa}$, moisture content $6.53 \%$, temperature $100^{\circ} \mathrm{C}$ and holding time $30 \mathrm{~min}$. This result is in agreement with that published by Jha et al. (2008). 


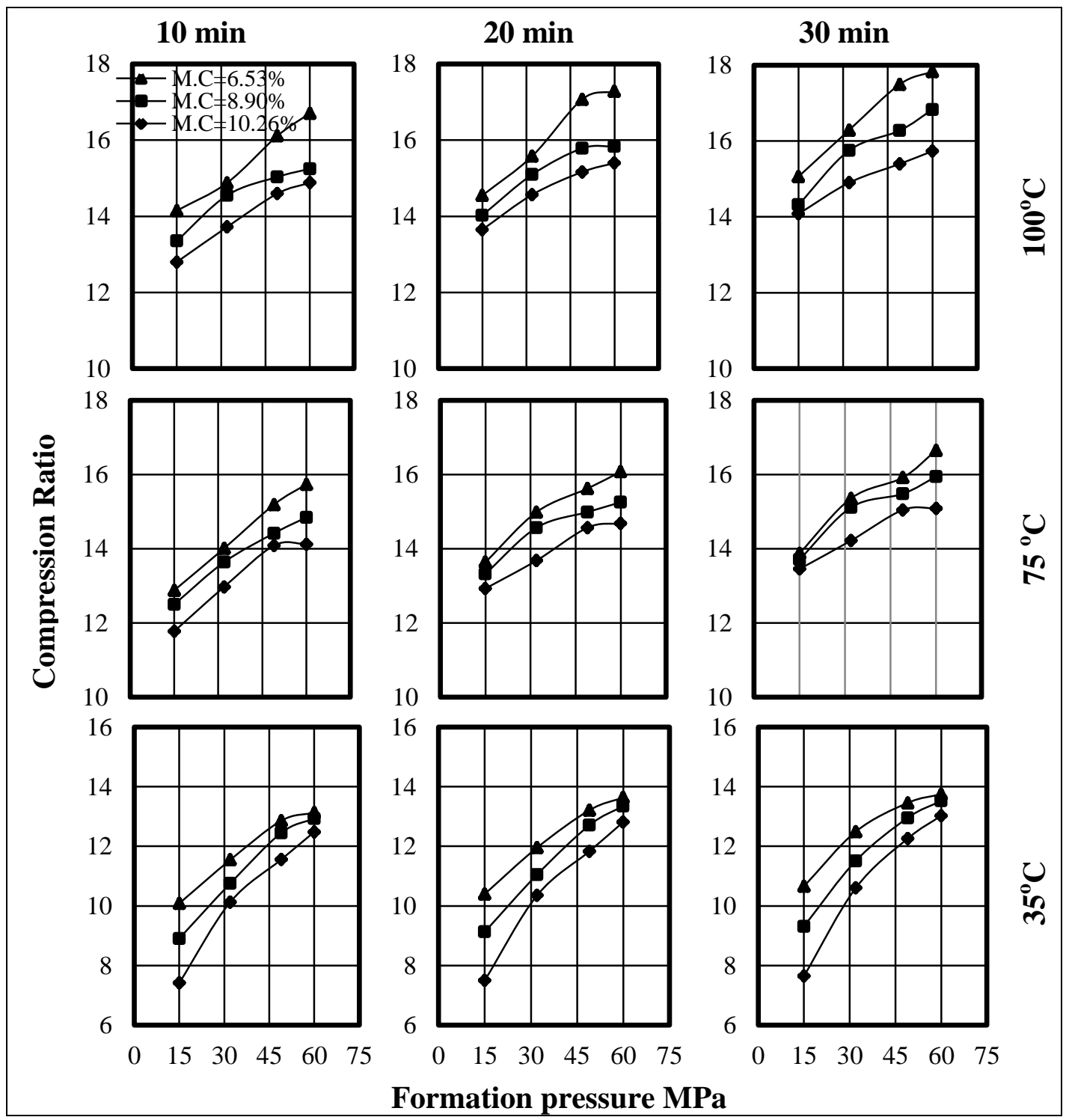

Fig. 5: Effect of formation pressure (MPa) on compression ratio at different holding times (min), moisture contents $(\%)$ and temperatures $\left({ }^{\circ} \mathrm{C}\right)$.

Effect of studied variables on water resistance for rice straw briquettes:

Fig (7) illustrates the relationship between water resistance and formation pressure $(\mathrm{MPa})$ at different holding times $(\mathrm{min})$, moisture contents $(\%)$ and temperatures $\left({ }^{\circ} \mathrm{C}\right)$ for rice straw briquettes. 


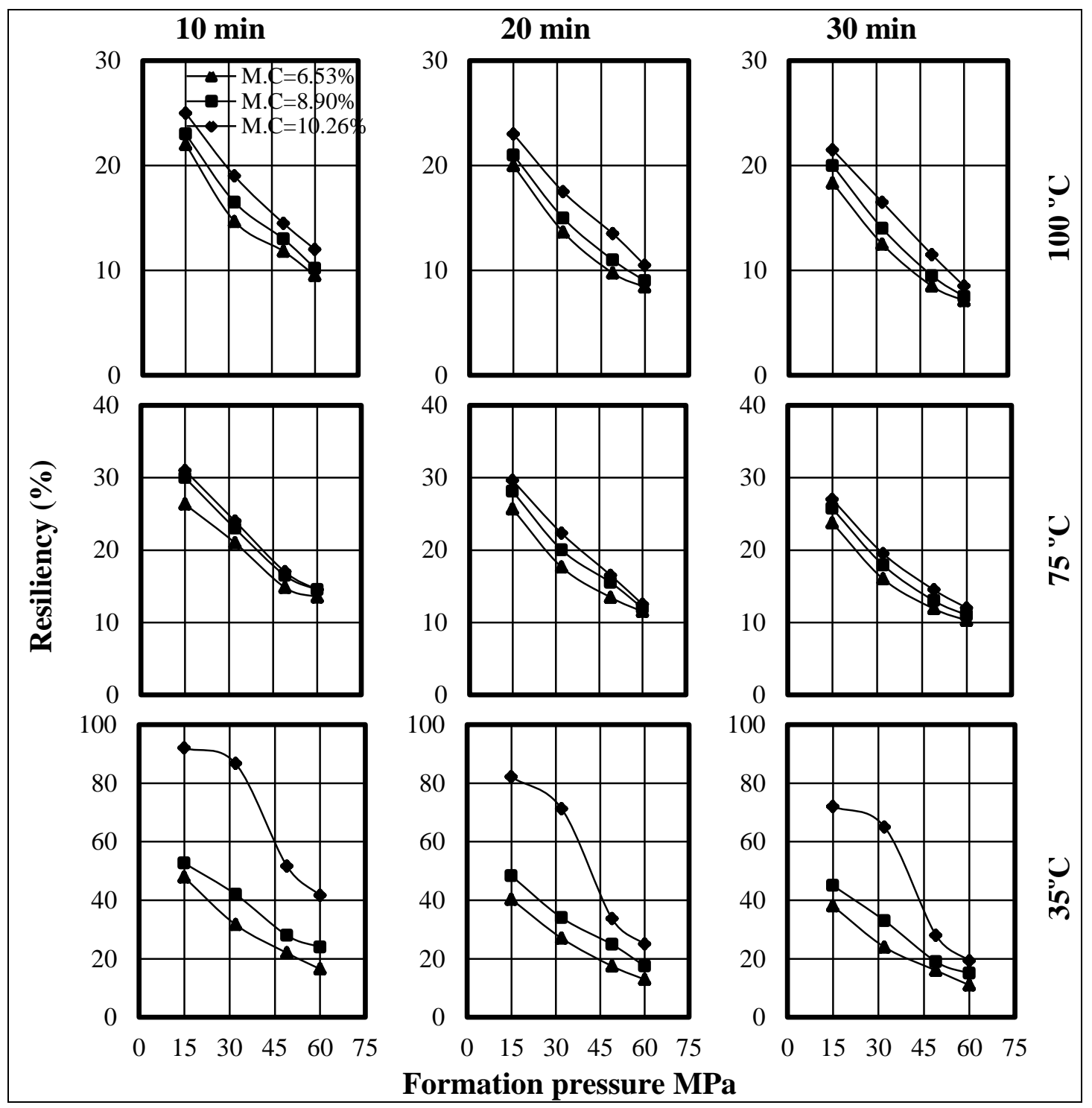

Fig. 6: Effect of formation pressure (MPa) on resiliency (\%) at different holding times (min), moisture contents $(\%)$ and temperatures $\left({ }^{\circ} \mathrm{C}\right)$.

The data indicated that the water resistance increases with formation pressure, temperatures and holding times increasing. While, water resistance decreases with moisture contents increasing.

The maximum water resistance obtained was about $107 \mathrm{~min}$ at formation pressure $60 \mathrm{MPa}$, moisture content $6.53 \%$, temperature $100^{\circ} \mathrm{C}$ and 
holding time $30 \mathrm{~min}$. While, the minimum water resistance obtained was about 22 min for rice straw briquettes at formation pressure $15 \mathrm{MPa}$, moisture content $10.26 \%$, room temperature $\left(35^{\circ} \mathrm{C}\right)$ and holding time 10 min. This result is in agreement with that published by Gomea et al. (2012).

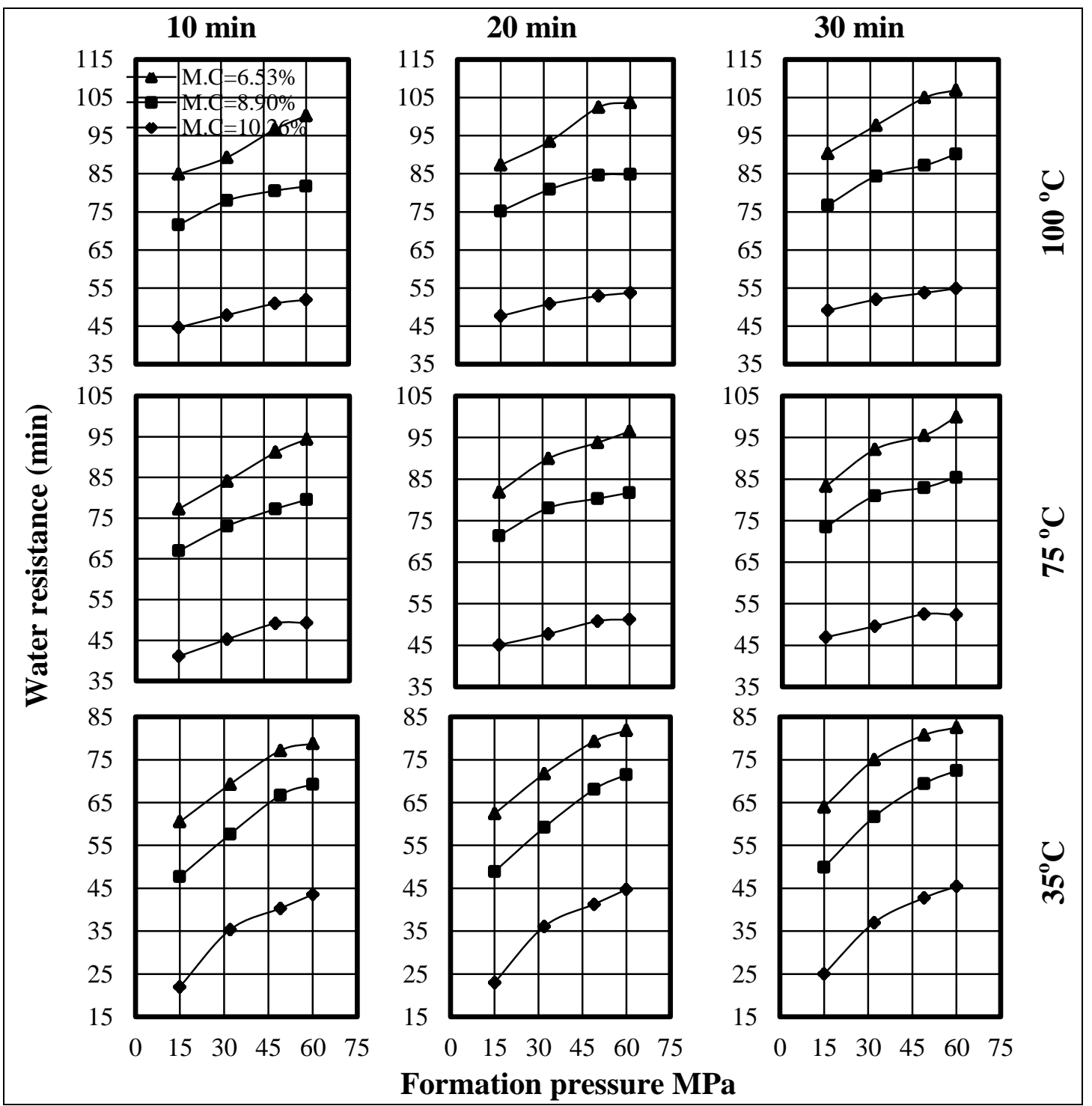

Fig. 7: Effect of formation pressure (MPa) on water resistance (min) at different holding times $(\mathrm{min})$, moisture contents $(\%)$ and temperatures $\left({ }^{\circ} \mathrm{C}\right)$. 
Effect of formation pressure, temperature and holding time at moisture content $6.53 \%$ on durability (\%) for rice straw briquettes:

Fig (8) illustrates the relationship between durability (\%) and formation pressure $(\mathrm{MPa})$ at different holding times $(\mathrm{min})$ and temperatures $\left({ }^{\circ} \mathrm{C}\right)$ for rice straw briquettes.

The obtain data shows that, for all experimental conditions, durability increases with formation pressure increasing from 15 to $60 \mathrm{MPa}$ under all experimental conditions. Also, increases temperature from room temperature $\left(35^{\circ} \mathrm{C}\right)$ to $100^{\circ} \mathrm{C}$ and holding time from 10 to $30 \mathrm{~min}$ increasing durability dramatically.

The maximum durability obtained was about $95 \%$ at formation pressure 60 $\mathrm{MPa}$, temperature $100^{\circ} \mathrm{C}$ and holding time $30 \mathrm{~min}$. While, the minimum durability obtained was about $61 \%$ for rice straw briquettes at formation pressure $15 \mathrm{MPa}$, room temperature and holding $10 \mathrm{~min}$.

\section{Measuring gases emissions:}

Table (3) shows the combustion results of chopped rice straw and rice straw briquettes. The data indicates that, the $\mathrm{CO}$ values of rice straw briquettes were lower by was $69 \%$ than the $\mathrm{CO}$ values of chopped rice straw. The $\mathrm{CO}_{2}$ values of rice straw briquettes were lower by $54 \%$ than the $\mathrm{CO}_{2}$ values of chopped rice straw. As well as $\mathrm{NO}_{\mathrm{x}}$ values of rice straw briquette were lower by $37 \%$ than the $\mathrm{NO}_{\mathrm{x}}$ values chopped rice straw. The combustion efficiency was $99 \%$ and $70 \%$ for rice straw briquettes and chopped rice straw, respectively, and the burning time was about 74 and 15 min for rice straw briquettes and chopped rice straw, respectively.

Table (3): Results of the combustion experiment.

\begin{tabular}{|c|c|c|c|c|c|}
\hline \multirow{3}{*}{ Item } & \multicolumn{3}{|c|}{ Gas emissions } & \multirow{2}{*}{$\eta$} & \multirow{2}{*}{$\begin{array}{c}\text { Burning } \\
\text { time }\end{array}$} \\
\hline & $\mathrm{CO}$ & $\mathrm{CO}_{2}$ & $\mathrm{NO}_{\mathrm{x}}$ & & \\
\hline & $\mathrm{mg} / \mathrm{m}^{3}$ & $\mathrm{mg} / \mathrm{m}^{3}$ & $\mathrm{mg} / \mathrm{m}^{3}$ & $\%$ & $\min$ \\
\hline Chopped rice straw & 1313 & 81856 & 62.1 & 70 & 15 \\
\hline Rice straw briquettes & 405 & 37523 & 38.8 & 99 & 74 \\
\hline
\end{tabular}




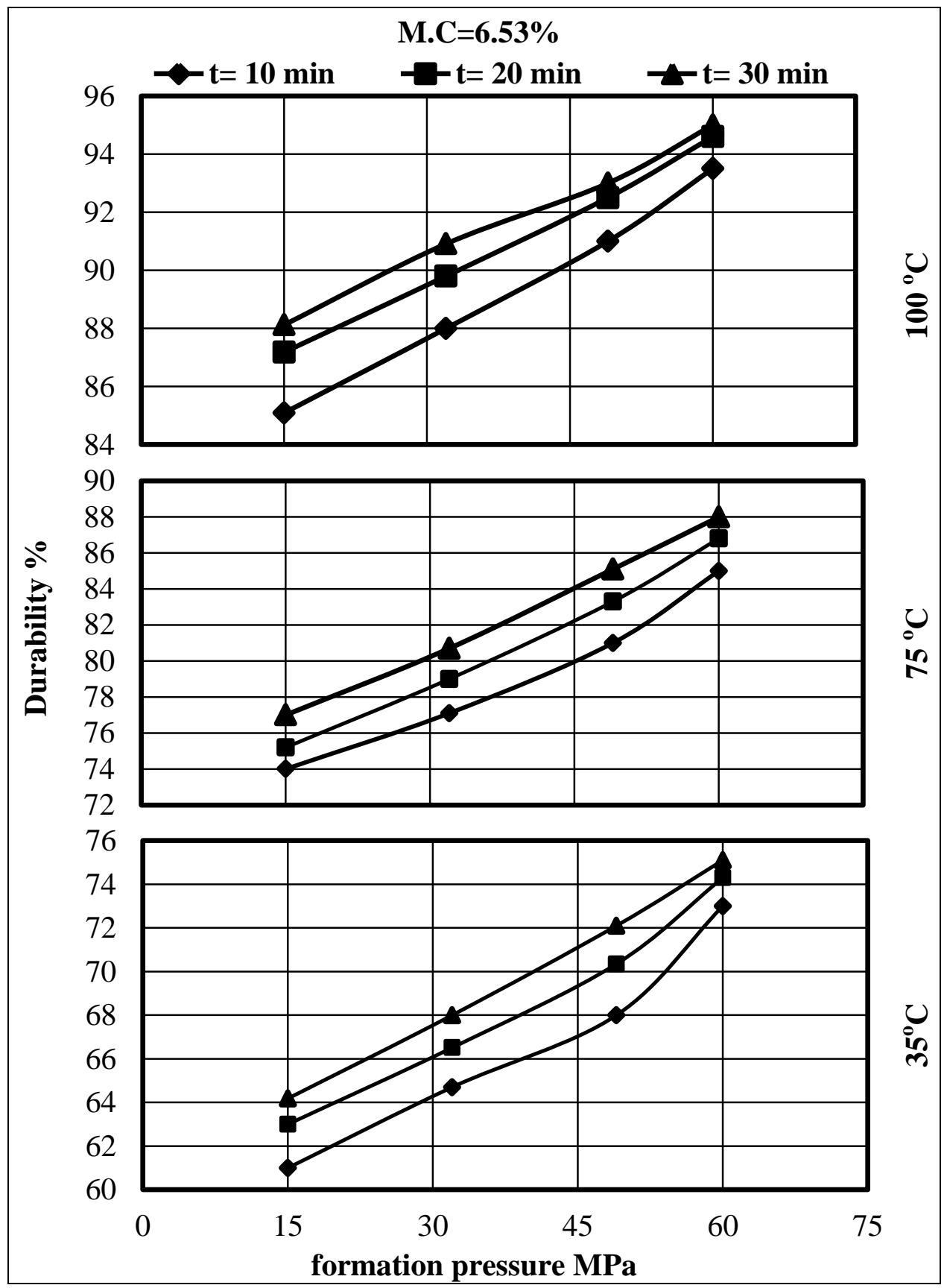

Fig. 8: Effect of formation pressure (MPa) on durability (\%) at different holding times $(\mathrm{min})$ and temperatures $\left({ }^{\circ} \mathrm{C}\right)$ for rice straw briquettes. 


\section{CONCLUSION}

Densification of biomass materials into briquettes could reduce problems with handling, transportation, storage, and utilization biomass materials to produce a good quality biofuel.

This research aimed to study some physical properties of rice straw briquettes. The quality properties of the produced rice straw briquettes were affected by formation pressure, moisture content, temperature and holding time.

The optimum quality properties of the briquettes were $60 \mathrm{MPa}$ formation pressure, $6.53 \%$ moisture content, $100^{\circ} \mathrm{C}$ temperature and $30 \mathrm{~min}$ holding time.

The maximum bulk density, compression ratio, durability and water resistance were $1337 \mathrm{~kg} / \mathrm{m}^{3}, 18,95 \%$ and $107 \mathrm{~min}$, respectively. While, the minimum resiliency obtained was $7.11 \%$. The $\mathrm{CO}, \mathrm{CO}_{2}$ and $\mathrm{NO}_{\mathrm{x}}$ emissions values for rice straw briquettes decreased by 69, 54 and $37 \%$, respectively, of the emissions values $\mathrm{CO}, \mathrm{CO}_{2}$ and $\mathrm{NO}_{\mathrm{x}}$ for chopped rice straw.

\section{REFERENCES}

ASAE Standard S269.4 (1996). Cubes, Pellets and Crumbles - Definition and methods for determining density, durability and moisture content.

Chin, O.C. and K.M. Siddiqui (2000). Characteristics of some biomass briquettes prepared under modest die pressures. Biomass and Bioenergy, 18: 223-228.

Debdoubi A., A. Elamarti and E. Colacio (2005). Production of fuel briquettes from esparto partially pyrolyzed, Energy Conversion and Management, 46, 1877-1884.

EL-Bessoumy R. R. (2005). Effect of using agricultural residues in building materials characteristic. MSC, Thesis. Ag. Eng. Dept., Faculty of Agriculture, Al-Azhar University.

El Saeidy E. (2004). Technological fundamentals of briquetting cotton stalks as a biofuel (Doctoral dissertation, Humboldt-Universität zu Berlin, Land wirtschaftlich - Gärtnerische Fakultät), Renewable Energy in Agriculture in Egypt, pp: 20-34. 
Fapetu, O. P. (2000). Production of charcoal from tropical biomass for industrial and metallurgical process. Nigeria Journal of Engineering Management, 1(2), 34-37.

Gamea, G. R.; E. A. El Saeidy; and S. F. El Sisi (2012). Quality properties for cotton stalks and rice straw briquettes. The 19th. Annual Conference of the Misr Soc. of Ag. Eng., 14-15 November, 2012: 303-324.

Jekayinfa S. O. and O. S. Omisakin (2005). The energy potentials of some agricultural wastes as local fuel materials in Nigeria. Agricultural Engineering International the CIGR E-Journal of Scientific Research and Development Vol., VII Manuscript E.E 05 003: 10Pp.

Jha S. K., A. Singh and A. Kumar (2008). Physical characteristics of compressed cotton stalks. Biomass Engineering, 99, $205-210$.

MALR (2013). Ministry of Agriculture and Land Reclamation, Agricultural research Centre, The weather monthly report, Egypt.

Mullen, J.; O. O. Fasina.; C. W. Wood.; and Y. Feng (2005). Storage and handling characteristics of pellets from poultry litter". Applied Engineering in Agriculture, 21, 645-51.

Nalladurai, K.; and R. V. Morey (2009). Factors affecting strength and durability of densified biomass products". Biomass and Bio-energy, 33, $337-359$.

Nalladurai, K.; and R. V. Morey (2010). Natural binders and solid bridge type binding mechanisms in briquettes and pellets made from corn Stover and switchgras. Bioresource Technology, 101, 1082-1090.

Panwar, V.; B. Prasad.; and K. L. Wasewar (2011). Biomass Residue Briquetting and Characterization. J. Energy Eng.-ASCE 137, 108-114.

Yaman S., M. Sahan, H. Haykiri-Acma, K. Şeşen and S. Küçükbayrak (2001). Fuel briquettes from biomass-lignite blends. Fuel processing technology, 72(1), 1-8.

Wilaipon, P (2007). Physical Characteristics of Maize Cob Briquette under Moderate Die Pressure. The 2nd International Conference on Thermal Engineering and Applications. United Arab Emirates, Jan 3-6, 2006. UAE University. 


\section{الملخص العربيى \\ بعض الخصائص الفزيائية لقوالب قش الارز}

أ.د إبراهيم سبف أحمد السؤالي * ، د. رزق ربيع كامل البسومي *** و م. أحمد السيد محمود فوده **** أصبح استخدام الطاقة الجديدة والمتجددة ضرورة ملحة نتيجة للنضوب السريع للوقود التقليدي وتعتبر الكتلة الحيوية من أكبر مصادر الطاقة الجديدة والمتجددة لتو افر ها و إنخفاض السعار التهار ها.

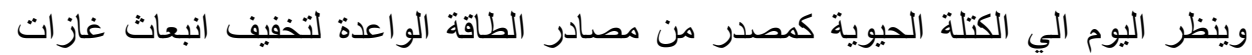
الاحتباس الحراري وبالتالي يؤدي الي تحسين الظروف البيئية المحيطة. وتعتبر المخلفات

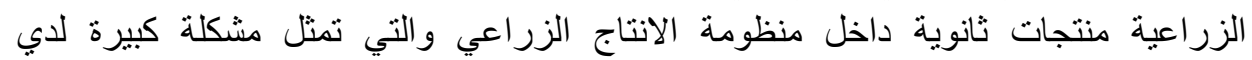

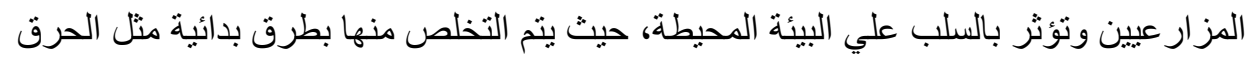

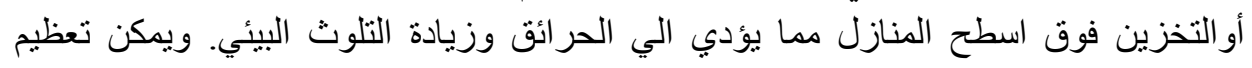
الاستفادة من هذه المخلفات بتحويلها الي طاقة نظيفة مما يساهم في حماية البيئة من التلوث

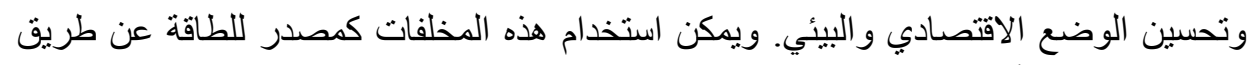
تكنولوجيا القولبة أو التكثيف. التحفئ.

\section{الهذف من هذة الدراسة هو قولبة قش الأرز للوصول إلى الأهداف التالية:}

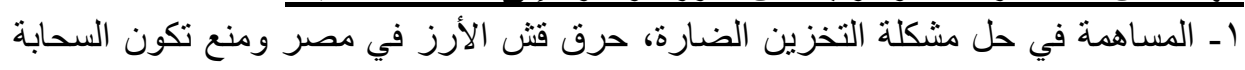

$$
\text { السوداء. }
$$

rـ الحفاظ علي البيئة والزر اعة بالتعامل مع هذة المخلفات بطريقة آمنة. بـ إنتاج وقود حيوي صلب رخيص، قابل للتخزين بسهولة، وسليم بيئيا في المناطق الريفية المصرية.

\section{لتحقيق الأهداف السابقة تم إجراء الخطوات التالية:}

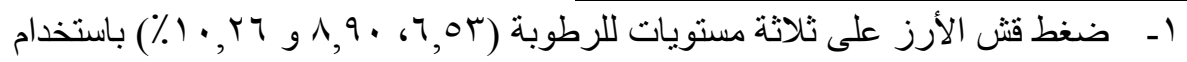

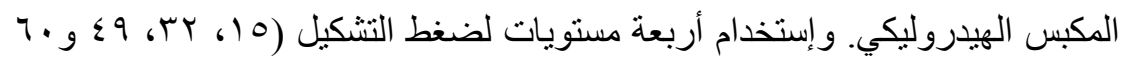

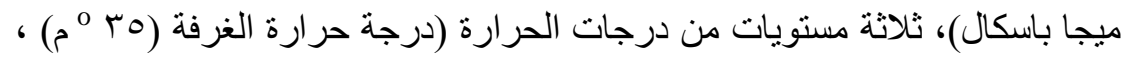

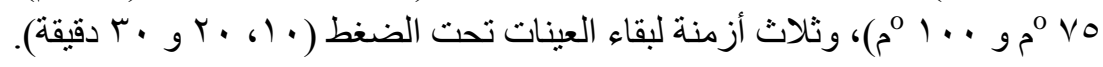

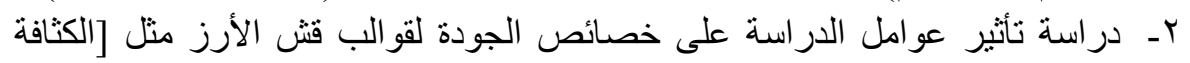

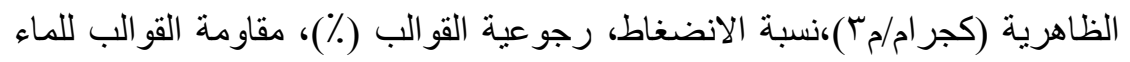

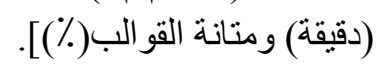

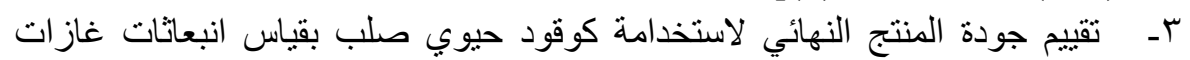

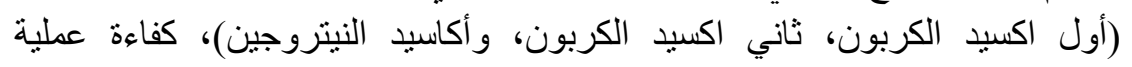

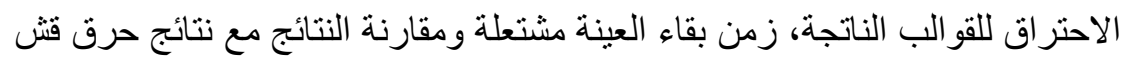

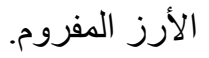

* أستاذ هندسة المنشآت الزراعية و التحكم البيئي ـ كلية الهندسة الزراعية - جامعة الأزهر - القاهرة.

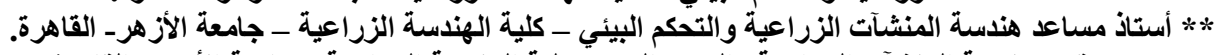

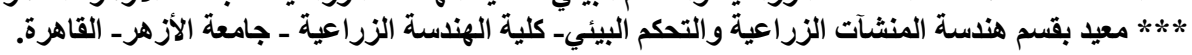




\section{كاتت أهم النتائج التى تم الحصول عليها كالتاللى:}

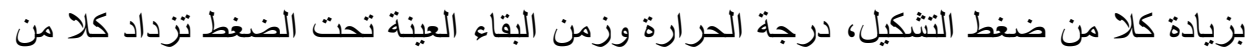
الكثافة الظاهرية، نسبة الانضغاط، ومقاومة القو الب للماء و المتانة للقو الب الناتجة بينما تزداد الرجوعية. ولكن بزيادة المحتوي الرطوبي تقل كلا من الكثافة الظاهرية، نسبة الانضغاط، ولة الانة

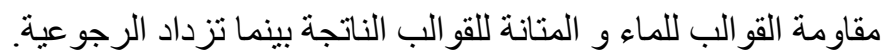

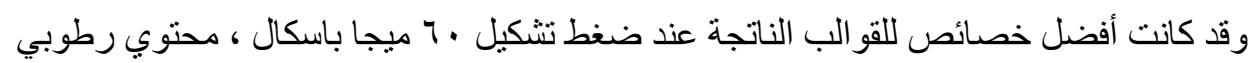

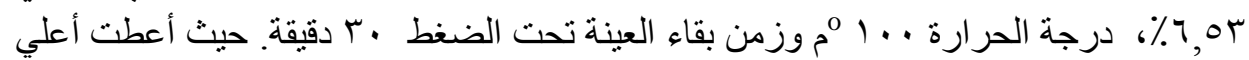

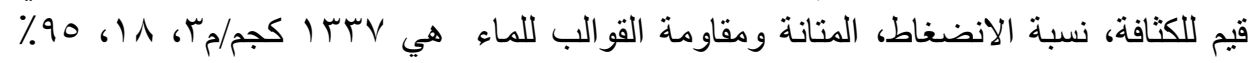

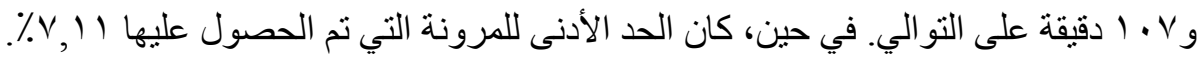

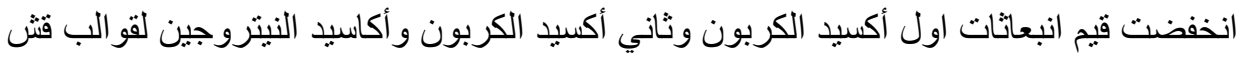

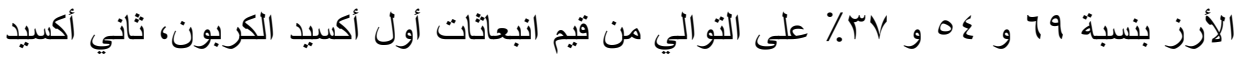

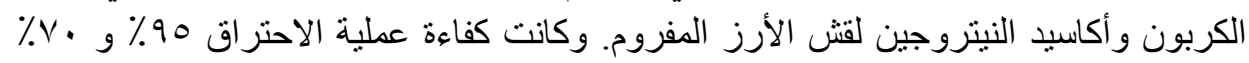

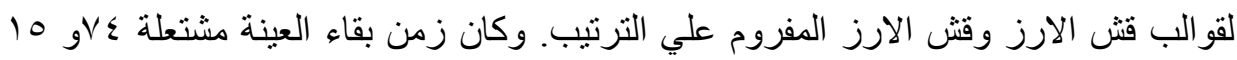

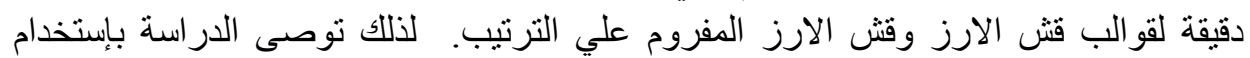
قو الب قش الارز كوقود صديق للبيئة. 